\title{
ANALYSIS OF THE IMPACT OF MAXIMUM VEHICLE LOAD AT THE AGE OF FLEXIBLE PAVEMENT (CASE STUDY OF THE ROAD SECTION OF HERA DILI TIMOR-LESTE
}

\author{
Junizia Elsa De Almeida \\ Faculty of Engineering \\ Civil Engineering Program \\ Narotama University, Surabaya \\ Junizia0606@gmail.com \\ Koespiadi \\ Faculty of Engineering \\ Civil Engineering Program \\ Narotama University, Surabaya \\ koespiadi@narotama.co.id
}

\begin{abstract}
The road network is a land transportation infrastructure that plays an important role in the transportation sector, especially for the balance of the distribution of goods and services, both from other regions. In this study, an analysis was conducted to find out how the influence of heavy vehicle volume increase on the service life of the road, while the method used was Bina Marga, the study was conducted by taking a case study on the Hera road section until Dili. This research is expected to find out how the service life of the road if the volume of heavy vehicles continues to increase. If the\% of heavy vehicles increase, the thickness of the required surface layer will also be even greater. When\% of vehicles or carrying heavy traffic loads are increased, the thickness of the existing layer cannot meet, because the calculation results with\% of heavy vehicles increase by $10 \%$, surface thickness $17.2 \mathrm{~cm} /$ This will cause the service life of the road to decrease, because it is confirmed that the road will be damaged before the service period ends due to excessive load increase in heavy vehicles.
\end{abstract}

Keywords : Flexible Pavement, Existing Condition, Heavy Vehicle 10\%

\section{INTRODUCTION}

The highway is a land transportation infrastructure that plays an important role in the transportation sector, especially for the balance of distribution of goods and services, from other regions. Therefore, the important condition for the development and wellbeing of society is a good and useful transportation system. The existence of highways is indispensable to support the pace of economic growth often with the increasing need for transportation means that can launch transportation in Hera, is a regional/arterial road which includes serving a quick traffic between the Distric and small village village.

Based on the background above, the formulation of the problem is as follows:

a. How much is the maximum vehicle burden on the perularity of Hera-Dili road segment?

b. How is the relationship of percentage value increase in heavy vehicles with age on bending in the road of Hera?

c. How is the thick condition of the ethical layer when the percentage value of heavy vehicles increases? 


\section{Research objectives}

a. To find out how much the maximum vehicle burden on the perularity of the Hera-Dili road segment.

b. To know the relationship of percentage of heavy vehicles with age on bending of the road to Hera.

c. To be in the thick of existing coating to influence the increase in the volume of heavy vehicle traffic.

\section{LITERATURE REVIEW}

\section{Definition of road Perkerasan}

Road perlashing Construction is a layer that is compacted with or without a binder layer above the ground layer on a road path. If the construction is planned to use a binding coating, a common binding layer is used for asphalt or cement coating. With the construction of road piping, the road will be protected from damage mainly caused by water and traffic loads where road perlimation construction will strengthen the carrying capacity of land weakened by water.

\section{Types and functions of bending pliable construction}

The seam coating is the construction above the ground that serves to carry the traffic burden by providing a sense of security and comfort. The awarding of a construction layer is intended to allow the tension to occur as a result of loading on the ground soil (subgrade). Road pavement construction is differentiated into two groups according to the bindings used, namely flexible pavements and rigid pavement (rigible). Flexure Pavement (flexibly) made from aggregates and asphalt. Rigit pavement layer is made of aggregate and cement material, consisting of one layer of concrete plate with or without bottom foundation (sub base) between the pavement and ground land (sub grade).

\section{Planning measures thick pliable bending with SNI method-1732-1989 F traffic load based on SNI 1732-1989-F}

Traffic expenses based on SNI 1732-1989-F are stated to cross an equivalent plan (LER) whose calculation measures are as follows:

1. The equivalent number (E) is calculated for each type of vehicle by first calculating the number of each axis equivalent. The formula to calculate the number is equivalent to single axis and double axis as below formula:

a. Single-axis equivalent (E) Number:

$$
E=\left(\frac{\text { Load Axis tun gal in } \mathrm{kg}}{8160}\right)^{4}
$$

b. Double-axis equivalent number $(\mathrm{E})$ :

$$
\left.\mathrm{E}=\frac{\text { Load Axis tun gal in } \mathrm{kg}}{8160}\right) 0,086 \times\left({ }^{4} \ldots\right.
$$

2. The LHR is calculated in the early age of the plan by using the formula below for each group of vehicle types. Early LHR-Age plans $=$

LHRs $x(1+a)^{n}$...

Description:

LHRs = LHR Data collection results

A = Traffic growth factor from the moment of data collection until the start of the

plan age. $\quad n=$ length of time from the data collection until the start of the plan age. The vehicle distribution factor in the planned path is determined based on the number of road lines. 
3. The initial-equivalent cross-rates (LEP) as a preliminary-to-early-age plan are calculated using this damlied formula:

$$
\begin{aligned}
& \text { LEP }=\sum_{j-1}^{n} \operatorname{LHRj} \times \mathrm{Cj} \times \mathrm{Ej} \\
& \text { Description: } \\
& \text { LEP = advance equivalent of age plan } \\
& \mathrm{J}=\text { Vehicle type } \\
& \mathrm{N}=\text { Year of observation } \\
& \mathrm{LHRj}=\text { Average Daily traffic } \\
& \mathrm{C} \mathrm{j}=\text { vehicle distribution coefficient }(\mathrm{C}) \text {, and } \\
& \mathrm{Ej}=\text { number of vehicle axis equivalent }(\mathrm{E}) \text { load }
\end{aligned}
$$

4. The final-equivalent cross (LEA) as a cross-end equivalent of the plan age is calculated using the following formula:

$$
\begin{aligned}
& \text { LEA }=\text { LEP }(1+i) \text { UR } \\
& \text { Description: } \\
& \text { LEA }=\text { Cross equivalent at end of age plan } \\
& \text { LEP }=\text { cross the equivalent in the initial age of the plan } \\
& \text { I }=\text { Traffic growth factor } \\
& \text { UR }=\text { Age plan. }
\end{aligned}
$$

5. The middle equivalent (LET) cross is calculated with the following formula:

$$
\begin{aligned}
& \text { LET }=0,5 \times(\text { LEP }+ \text { LEA }) \\
& \text { Keterangan : } \\
& \text { LET }=\text { middle equivalent } \\
& \text { LEP = Beginning of the initial equivalent } \\
& \text { LEA = last-equivalent cross. }
\end{aligned}
$$

6. A cross-equivalent plan (LER) is calculated by the following formula:

$$
\text { LER }=\text { LET } \times \text { FP }
$$

7. The adjustment factor (FP) above is determined by the following formula:

$$
\mathrm{FP}=\mathrm{UR} / 10
$$

\section{Index thickness of Pavement (ITP) According to SNI 1732-1989-F.}

Thickness of the pavement sought with the help of nomogram, thick index of the pavement (ITP) obtained by connecting DDT and LER, then IPT connected with regional factors (FR) will be obtained the plan thickness index. The thick alignment of each layer is calculated by the following formula:

$$
\begin{gathered}
\mathrm{ITP}=\mathrm{a} 1 \mathrm{D} 1+\mathrm{a} 2 \mathrm{D} 2+\mathrm{a} 3 \mathrm{D} 3 \\
\text { Description: }
\end{gathered}
$$


ITP $=$ Thickness index

A1 = relative strength coefficient of surface layer.

$\mathrm{A} 2$ = relative strength coefficient of upper foundation layer.

$\mathrm{A} 3=$ relative strength coefficient of bottom foundation .

D1 = thickness of the surface layer.

D2 $=$ thickness of upper Foundation layer.

D3 = Bold Bottom foundation layer.

\section{RESEARCH METHODOLOGY}

A methodology is a way or step used to solve a problem by collecting, measuring, studying, and analyzing the data gained by achieving a purpose. To achieve the results of systematic research, organized and can run effectively, efficiently and on target, a design of research, research methods and methods of analysis used. And in the draft research tailored to the purpose of the research, the nature of problems discussed in the completion model.

\section{Types of research}

As a first step of research is knowing the type of research that will be done based on the purpose of the research. By observing the known issues in the preparation of this final task, this type of research is relevant to support the analysis process to solve a problem. As a first step in this study, the problems that you want to solve should be clearly identified to avoid the confusion that can arise, as well as the case study that will be done.

\section{Data Source Determination}

Determination of data sources consisting of:

The data used to support authors in this writing is primary data, secondary data. Primary data is obtained directly on the research site while secondary data is obtained from the construction authorities, in this case the CICO company.

\section{Research procedure}

Research is conducted in the following procedures:

a. Data collection in the form of primary data and secondary data.

b. Calculation and analysis of data

c. Steps to calculate the Bina Marga method

1. Early LHR calculation of age plans

2. The LHR calculation at the end of age plan

3. Vehicle distribution coefficient $(\mathrm{C})$ 
4. The equivalent number $(E)$ is calculated for each type of each axis.

5. Initial-equivalent (LEP) cross-value calculation

$\mathrm{LEP}=\mathrm{LHRj} \times \mathrm{Cj} \times \mathrm{Ej}$

6. Final equivalent (LEA)

$\mathrm{LHR}=\mathrm{LHR} \times(1+\mathrm{i})^{\mathrm{n}}$

7. The middle equivalent (LET) cross is calculated with the following formula:

LET $=0.5 \times($ LEP + LEA $)$

8. A cross-equivalent plan (LER) is calculated by the following formula:

LER $=$ LET $\times$ FP

9. Formulation factor (FP) formula

$F P=U R / 10$

10. Ground carrying Capacity (DDT) Determination of correlation between the values of DDT and CBR DDT $=4.3 \log \mathrm{CBR}+1.7$

11. The surface Index at the beginning of the Plan Life (IPo) is determined by surface layer type.

12. The surface Index at the end of the Plan Age (IPt) is determined based on the number of LER and road classification.

13. Thickness Index (ITP) is determined from nomograms by using the value of DDT, LHR and FR.

14. Nomograms are determined based on the Ipo and IPT values

15. Specify the minimum thickness of the perlayer and the coefficient (a) of each layer.

16. Calculating the thickness layer

$$
D 1=\frac{I T P-(a 2 \cdot D 2+a 3 \cdot D 3)}{a 1}
$$

\section{RESULT AND DISCUSSION}

\section{Existing condition of Perkerasan}

The road in the analysis of the roads are as follows:

$\begin{array}{ll}\text { Road type } & : \text { Alteri } \\ \text { Hard Layer Type } & : \text { Flexible Pavement (flexure) } \\ \text { Thickness for } 1 \text { lane and } 2 \text { directions. } \\ \text { Track width } & : 8 \mathrm{~m} \\ \text { Street Shoulder width } & :(1 \times 2) \mathrm{m} \\ \text { Terrain conditions } & : \text { Straight and flat }<6 \% \\ \text { Age Plan } & : 10 \text { years old }\end{array}$

\section{Traffic Volume}

To analyze the road then data then Linta is a major factor in analyzing to determine the road class and as well as to determine the thick of the alignment layer. The traffic Data used by the authors in this analysis is obtained from the contractor CICO. The traffic data can be seen in the table 4.1 . 


\begin{tabular}{|c|c|c|c|}
\hline Type of Vehicle Weight & Total & $\begin{array}{c}\text { Volume } \\
\text { Traffic }\end{array}$ & Unit \\
\hline Passenger car & 2 Ton & 153 & Vehicle \\
\hline Light truck & 8 Ton & 129 & Vehicle \\
\hline Bus & 9 Ton & 59 & Vehicle \\
\hline truck weight & 13 Tons & 45 & Vehicle \\
\hline Truck 3 axles & 23 Tons & 47 & Vehicle \\
\hline
\end{tabular}

\section{Heavy Drive Calculations}

The percentage of weight to total vehicles is:

$$
\begin{aligned}
& =\frac{129+59+45+47}{153+129+59+45+47} \times 100 \% \\
& =\frac{153}{306} \times 100 \% \\
& =50 \%
\end{aligned}
$$

$10 \%$ weight vehicle percentage.

1. Passenger cars $=153=153$

2. Light Truck $=59 \times 1.1=141.9$

3. Bus $=59 \times 1.1=64.9$

4. Heavy Truck $=45 \times 1.1=49.5$

5. Truck 3 AS $=47 \times 1.1=51.7$

a. Existing Data, (10-year plan)

Existing Data for the age of plan 10 years as follows: The layer of pavement is a surface with a thickness of $7 \mathrm{~cm}$, a base course with a thickness of $15 \mathrm{~cm}$, a sub base course with a thickness of $20 \mathrm{~cm}$.

\begin{tabular}{|c|c|c|c|c|c|c|c|}
\hline Passenger cars & $=$ & 153 & $x$ & $(1+0.06)^{5}$ & $=$ & 204.749 & Vehicle \\
\hline Light Truck & $=$ & 141.9 & $x$ & $(1+0.06)^{5}$ & $=$ & 189.894 & Vehicle \\
\hline Bus & $=$ & 64.9 & $x$ & $(1+0.06)^{5}$ & $=$ & 86.851 & Vehic \\
\hline Heavy Truck & $=$ & 49.5 & $x$ & $(1+0.06)^{5}$ & $=$ & 66.242 & Vehi \\
\hline Truck 3 AS & $=$ & 51.7 & $x$ & $(1+0.06)^{5}$ & $=$ & 69.186 & \\
\hline
\end{tabular}

LHR Early Life plan $=5$ years (age of plagiarism)

$\operatorname{LHR} x(1+\mathrm{i})^{\mathrm{n}}$

b. End of age plan $=10$ years (Plan age)

$\operatorname{LHRx}(1+\mathrm{i})^{\mathrm{n}}$

Passenger cars $=204.749 \times(1+0.06)^{10}=366.673$ Vehicle 


$\begin{array}{lllllll}\text { Light Truck } & =189.894 \times(1+0.06)^{10} & =340.072 & \text { Vehicle } \\ \text { Bus } & =86.8508 \times(1+0.06)^{10} & =155.537 & \text { Vehicle } \\ \text { Heavy Truck } & =66.2422 \times(1+0.06)^{10} & =118.630 \text { Vehicle } \\ \text { Truck 3 AS } & =69.1863 \times(1+0.06)^{10} & =123.902 \text { Vehicle }\end{array}$

c. End of Life plan $=20$ years (Plan age)

\begin{tabular}{|c|c|c|c|c|c|c|c|}
\hline & & & & $(1+0.06)$ & & & \\
\hline Passenger cars & $=$ & 204.749 & $x$ & $\begin{array}{l}10 \\
(1+0.06)\end{array}$ & $=$ & 656.656 & Vehicle \\
\hline Light Truck & $=$ & 189.894 & $\mathrm{x}$ & $\begin{array}{l}10 \\
(1+0.06)\end{array}$ & $=$ & 609.016 & Vehicle \\
\hline Bus & $=$ & 86.851 & $x$ & $\begin{array}{l}10 \\
(1+0.06)\end{array}$ & $=$ & 278.542 & Vehicle \\
\hline Heavy Truck & $=$ & 66.242 & $\mathrm{x}$ & $\begin{array}{l}10 \\
(1+0.06)\end{array}$ & $=$ & 212.448 & Vehicle \\
\hline Truck 3 AS & $=$ & 69.186 & $x$ & 10 & $=$ & 221.890 & Vehicle \\
\hline
\end{tabular}

\section{Fatigue Data Analysis}

Maximum fatigue is determined based on long section data of 10.28\% STA: $91+000-94+$ 000

Equivalent and cross equivalent number calculation

The cross-equivalent calculations are based on the vehicle axis load for single axis and double axis. Calculation of the equivalent number of each vehicle (E) with Microsoft Excel application based on the formula below

1. Passenger cars $=E_{\text {Front axis }}+E_{\text {Rear axis }}$

$$
\begin{aligned}
& =(1000 / 8160)^{4}+(1000 / 8160)^{4} \\
& =0.0002+0.00002=0.0005
\end{aligned}
$$

2. Light Truck $=E_{\text {Front axis }}+E_{\text {Rear axis }}$

$$
\begin{aligned}
& =(3000 / 8160)^{4}+(5000 / 8160)^{4} \\
& =0.0183+0.0141=0.1592
\end{aligned}
$$

3. Bus $=E_{\text {Front axis }}+E_{\text {Rear axis }}$

$$
\begin{aligned}
& =(3000 / 8160)^{4}+(6000 / 8160)^{4} \\
& =0.0183+0.292=0.0183
\end{aligned}
$$

4. Heavy Truck $=E_{\text {Front axis }}+E_{\text {Rear axis }}$

$$
\begin{gathered}
=(5000 / 8160)^{4}+(8000 / 8160)^{4} \\
=0.1410+0.9238=1.0648
\end{gathered}
$$

5. Truck 3 as $=E_{\text {Front axis }}+E_{\text {Rear axis }}$

$$
\begin{aligned}
& =(5000 / 8160)^{4}+0.086 \times(18000 / 8160)^{4} \\
& =0.1410+2.0362=2.1772
\end{aligned}
$$

\section{Vehicle distribution coefficient (C)}

Based on the magnification width and the number of lanes, the road segments of Rua Hera have an $8 \mathrm{~m}$ wide road, where the $\mathrm{L}$ is $<5.5 \mathrm{~m}$ based. Table 2.2, the road section of Rua 
Hera is 12-way line, so it can be determined the value of vehicle distribution coefficient $(C)$ as follows;

a. Light vehicle with a total weight of $<5$ ton $\mathrm{C}=0.50$

b. Heavy vehicles with total weight $\geq 5$ tons $C=0.50$

\section{Initial (LEP) cross-value calculation}

LEP (2019) for the age of plans 10 years 20 years is as follows:

$\operatorname{LEP}_{(2019)}=\operatorname{LHR}(2019) \times \mathrm{Cj} \times \mathrm{Ej}$

Passenger

\begin{tabular}{|c|c|c|c|c|c|c|c|c|c|}
\hline cars & $=$ & 204.749 & $x$ & 0.50 & $x$ & 0.0005 & $=$ & 0.046 & Cross \\
\hline Light Truck & $=$ & 189.894 & $x$ & 0.50 & $x$ & 0.1592 & $=$ & 15.119 & Cross \\
\hline Bus & $=$ & 86.8508 & $x$ & 0.50 & $x$ & 0.0183 & $=$ & 0.793 & Cross \\
\hline Heavy Truck & $=$ & 66.2422 & $x$ & 0.50 & $x$ & 1.0648 & $=$ & 35.268 & $\begin{array}{l}\text { Cross } \\
\text { Cross }\end{array}$ \\
\hline Truck 3 as & $=$ & 69.1863 & $x$ & 0.50 & $x$ & 2.1772 & $=$ & $\begin{array}{l}75.316 \\
126.543\end{array}$ & + \\
\hline
\end{tabular}

A. $\operatorname{LEA}_{(2029)}=\operatorname{LHR}(2029) \times \mathrm{Cj} \times \mathrm{Ej}$

\begin{tabular}{llllllllll} 
Passenger cars & $=$ & 366.673 & $\times$ & 0.50 & $\times$ & 0.0005 & $=$ & 0.083 & Cross \\
Light Truck & $=$ & 340.072 & $\times$ & 0.50 & $\times$ & 0.1592 & $=27.076$ & Cross \\
Bus & $=155.537$ & $\times$ & 0.50 & $\times$ & 0.0183 & $=1.421$ & Cross \\
Heavy Truck & $=118.63$ & $\times$ & 0.50 & $\times$ & 1.0648 & $=63.159$ & Cross \\
Truck 3 as & $=123.902$ & $\times$ & 0.50 & $\times$ & 2.1772 & $=$ & 134.880 & Cross + \\
\hline
\end{tabular}

B. $\operatorname{LEA}_{(2039)}=\operatorname{LHR}(2039) \times \mathrm{Cj} \times \mathrm{Ej}$

$\begin{array}{llllllllll}\text { Passenger cars } & =656.656 & \times & 0.5 & \times & 0.0005 & = & 0.148 & \text { Cross } \\ \text { Light Truck } & = & 609.016 & \times & 0.5 & \times & 0.1592 & =48.489 & \text { Cross } \\ \text { Bus } & = & 278.542 & \times & 0.5 & \times & 0.0183 & =2.544 & \text { Cross } \\ \text { Heavy Truck } & =212.448 & \times & 0.5 & \times & 1.0648 & =113.108 & \text { Cross } \\ \text { Cross } & \\ \text { Truck 3 as } & =221.890 & \times & 0.5 & \times & 2.1772 & =\frac{241.549+}{405.839}\end{array}$

Central equivalent cross rate Perhitugan (LET)

$$
\begin{array}{ll}
\text { A. LET }_{(2029)} & =\frac{\operatorname{LEP}(2019)+\operatorname{LEA}(2029)}{2} \\
& =\frac{126.543+226.619}{2} \\
= & 239.852 \text { linta } \\
\text { B. } \operatorname{LET}_{(2039)} & =\frac{\operatorname{LEP}(2019)+\operatorname{LEA}(2039)}{2} \\
& =\frac{126.54+405.839}{2} \\
& =266.191 \text { Cross }
\end{array}
$$




\section{Calculation of the cross-equivalent value plan (LER)}

$$
\begin{aligned}
& \text { LER= LET } \times \text { FP } \\
& \begin{aligned}
\stackrel{F P}{\longrightarrow} & =\frac{\text { UR }}{10} \\
\text { A. LER }(2029)=\operatorname{LET}_{(2029)} \times \frac{10}{10}( & n=10 \text { Years }) \\
& =239.85 \times \frac{10}{10} \\
& =239.85 \text { Cross } \\
\text { B. LER (2039) }=\operatorname{LET}_{(2039) \times} \times \frac{20}{10}( & n=20 \text { Years }) \\
& =266.191 \times \frac{20}{10} \\
& =532.382 \text { Cross }
\end{aligned}
\end{aligned}
$$

\section{Regional Factors Determination (FR)}

Regional factors are determined based on the maximum rainfall value, road volume, heavy vehicle and geometric road presentations. Based on the above square parameters, the regional factors are determined:

- Maximum rainfall $988.61 \mathrm{~mm} / \mathrm{yr}$ (Climate II > 900).

- Presenatse vehicles weight $50 \%$ (>30\%).

Based on the data above information, from table 2.5 obtained the value of regional factors: 1.0

\section{Surface index on early age plan (IP0)}

Determining the initial surface index of the plan age based on the structure of the structural performance at the beginning of the plan age according to table 2.6

IP0 on this research is determined according to the type of a Rajadi piping layer with a smoothness value/roughness $>1000 \mathrm{~mm} / \mathrm{km}$.

$$
\mathrm{IP}_{0}=3.9-3.5
$$

\section{Surface index at start end of plan (IPt)}

Determination of final surface index of the plan age based on LER and road classification according to table 2.7 in literature review.

IPt on this study was determined according to the volume LER and arterial road classification.

$$
\begin{array}{ll}
\operatorname{LER}_{10} & \\
\mathrm{IP}_{10} & =2.0 \\
\operatorname{LER}_{20} & =532.382 \\
\mathrm{IP}_{20} & =2.0
\end{array}
$$

\section{Land support power calculation (DDT)}

Calculation of soil support power based on CBR value. The relationship between the value of land support and CBR value in accordance with the formula (2.4) The correlation of CBR and DDT in the literature review.

$$
\mathrm{DDT}=4.3^{*} \log \mathrm{CBR}+1.7
$$

Soil support Power (Sub Grade)

$$
\begin{aligned}
\mathrm{CBR}_{\text {sub grade }} & =4.5 \% \\
\mathrm{DDT}_{\text {sub grade }} & =4.3^{*} \log 4.5 \%+1.7
\end{aligned}
$$




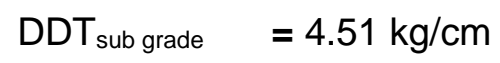

\section{Counting ITP Value}

1. For the 10-Year plan life

$\begin{array}{ll}\text { LER } & =239.865 \text { Lintas } \\ \text { IPt } & =2.0 \\ \text { IPo } & =3.9-3.5 \\ \text { FR } & =3\end{array}$

With the results of the analysis of the heavy vehicle Persenta from $10 \%-100 \%$ and the age of plans 10 and 20 years then we can use for bending, more than $100 \%$ of the percentage we can not use to calculate the bending of the pliable because it has passed of bending, to calculate the bending of the flexure, cross-equivalent plans in the limit of 10,000 .

Table 4.5 Thickness Thickness

\begin{tabular}{|c|c|c|c|}
\hline $\begin{array}{l}\% \text { Heavy } \\
\text { Vehicles }\end{array}$ & $\begin{array}{c}10 \\
\text { years } \\
\text { old }\end{array}$ & $\begin{array}{c}20 \\
\text { years } \\
\text { old }\end{array}$ & $\begin{array}{l}\text { Yield of } \\
100 \%\end{array}$ \\
\hline 10 & 15.6 & 20.9 & 34.000 \\
\hline 20 & 20.3 & 28.8 & 41.538 \\
\hline 30 & 21.9 & 29.7 & 35.714 \\
\hline 40 & 24.1 & 33.4 & 38.961 \\
\hline 50 & 25.6 & 34.1 & 32.927 \\
\hline 60 & 27.8 & 35.3 & 26.966 \\
\hline 70 & 30.3 & 37.2 & 22.680 \\
\hline 80 & 31.9 & 39.7 & 24.510 \\
\hline 90 & 35.0 & 41.6 & 18.750 \\
\hline 100 & 35.9 & 43.4 & 20.870 \\
\hline Total & & & 296.917 \\
\hline \multicolumn{3}{|c|}{$\begin{array}{c}\text { Results of the analysis of } 10 \% \\
\text { of vehicles }\end{array}$} & 29.692 \\
\hline
\end{tabular}

\section{CONCLUSION}

\section{A. Conclusion}

Based on results of the results of existing discussions can be taken several conclusions as follows:

1. Result of thick analysis of bending ply layer using Bina Marga Degan method for the age plan 10 years using thick existing lapis with the assumption obtained from contractor CICO, Degan (existing) layer of alignment surface $7 \mathrm{~cm}$, base $15 \mathrm{~cm}$, sub base $20 \mathrm{CM}$ Plan age 20 years.

2. If the\% of heavy vehicles are blocked then the thick layer surface required will also be larger.

3. When \% of vehicles or carrying the burden of existing traffic is heavily estimated, then the layer thickness is not able to meet, because the results of calculations with $\%$ of heavy vehicles 
increased $10 \%$ of the surface thickness is $17.2 \mathrm{~cm} /$ This causes the traffic time will be Berkuran, because it is ensured that the road will be damaged as the time of its load ends due to overburden of heavy vehicle

\section{Suggestions}

Based on the benefits of research and limitation of problems in CHAPTER I, the authors suggest the following things:

1. For readers who want to develop this research to review traffic volume data to re-analyze the percentage of the weight of $10 \%$ to $100 \%$.

2. For planners, executor and owner, should be more thorough in data collection, especially traffic survey data and traffic growth analysis because it is very influential in the value of thick index of the pavement (ITP).

\section{REFERENCES}

[1] Afrizal, E. K. ( 2014). Analysis of the overcharge influence on the age of road piping plans.

[2] Alkhairi, M. (2015). Impact analysis on the weight reduction plan for road Perdreasan..

[3] Anonymous. (2004). Guideline for drafting the practice of three technical faculties Diploma. Aceh:. University of the Hong.

[4] Asyanto, I. (2008 ). Road project construction methods. Jakarta:. University of Indonesia.

[5] Saodang, I. H. (2004). Highway construction. Bandung:. Nova.

[6] Eko Agus Nugroho, S. T. (2013). Influence of vehicle number to damage Grade II asphalt road in. Semarang District.

[7] Fropil, J. P. (2016). Analysis of thick bending pliable design using method Pd T-012002-B, Manual design of perching (MDP) and Nottingham method. Journal of Transportation, 4, 140-155.

[8] Jati Utomo. (2016). Evaluation of flood influence, overload and quality of construction on road conditions. (October), $11-13$.

[9] Muhamad Amin., \&. Y. (2011). Plan your way to load more with the method of Asstho..

[10] Muchtar., S. T. (2016). Recycling planning is based on road damage factors. Faculty of Engineering Universitas Teuku Umar alue Naga Peunyareng-Meulaboh.

[11] Sukirman Silvia. (2010, ). Planning thickness of bending structure; Publisher:. The London. 